UDC 378.016:811.111'243

DOI https://doi.org/10.32838/2663-6069/2020.2-2/02

Baybakova I. M.

Lviv Polytechnic National University

Hasko O. L.

Lviv Polytechnic National University

\title{
TIME MANAGEMENT SKILLS AS PART AND PARCEL OF ESP DISCOURSE MASTERING
}

The article is aimed at regarding time management in general and most essential strategies in particular as well as the corresponding skills necessary for students for the academic success, professional and job-related activities.

Due to learning environment changes, modern approaches to learning and technological developments it is necessary to support students in acquiring appropriate skills for planning their time and studies to be able to meet the requirements of the changed mode of tertiary educational process. Time management is considered as the effective use of time spent on some goal-directed activities.

Findings testify to the fact that in the majority of cases students focus on short-term planning demonstrating the lack of self-organization and prioritization skills in the long term learning. That is why they should be instructed to pay attention to: 1) setting goals correctly; 2) prioritizing wisely; 3) setting a time limit; 4) taking breaks between tasks; 5) organizing oneselves; 6) removing nonessential tasks; 7) planning ahead.

Time management techniques are regarded as the best way for managing course material. Through group study method, for example, students can have discussions exchanging ideas on certain topics and memorize their active vocabulary which help them to achieve better results, facilitate productivity and minimize stress.

Time management being a key ability and a fundamental skill properly taught and developed to increase the would-be-specialists' competitiveness in the current work market as well as their future successful functioning in the professional environment due to effective organization of the priorities and activities as a result of critical thinking, planning, defining objectives, applying beneficial strategies, team work, decision-making, problem resolving also influences a lifelong learning. Thus, all aspects of time management are highly evaluated within the ESP mastering and should be incorporated into tertiary educational process.

Key words: time management, higher education, teaching, learning, goal-directed activities, job related skills, ESP discourse.

Introduction. The article is aimed at regarding time management in general and most essential strategies in particular as well as the corresponding skills necessary for students for their academic success, professional and job-related activities.

Problem under consideration and its connection with important scientific and practical tasks. Time management is considered as the effective use of time spent on some goal-directed activities. Due to learning environment changes, modern approaches to learning and technological developments it is necessary to support students in acquiring necessary skills for planning their time and studies in a proper way to be able to meet the requirements of the changed mode of tertiary educational process.

Analysis of the research and publications on the issue under consideration. Time management has been in the focus of attention of many researchers. The article "A Review of Time Management Literature" by B. J. C. Claessens, W. van Eerde, C. G. Rutte and R. A. Roe [5] contains a thorough literature review and analysis of the problem under consideration. The authors distinguish several behaviour types concerning the issue: time assessment, planning and monitoring. M. Alvarez Sainz, A. M. Ferrero and A. Ugidos in their work "Time management: skills to learn and put into practice" [4] besides behaviour indicate other factors influencing the efficient organization of time, such as technical errors, external realities, psychological obstacles etc. They regard time management as one of educational process objectives.

The main body of the paper. Like our energy, time is a critical resource and as such, it needs to be effectively managed. Time management is about 
planning, controlling and dividing the amount of time spent between specific activities.

Time management is not one skill, it consists of a number of different skills and a good manager should clearly identify which skill in the set is not functioning effectively and letting a person down so that he/she could intervene and improve it.

Management scholar David Allen in his book "Getting Things Done: The Art of Stress-free Productivity" says that in today's world, yesterday's methods just don't work and he shares the effective methods for stress-free activities. His premise is simple: our productivity directly depends on our ability to relax. Only when our minds are clear and organized can we achieve effective results [3].

He proposes about sixteen essential time management skills which are of highest priority for one's productivity levels:

1. Setting up goals and not digressing from implementing them.

2. Prioritization: focusing on things that matter most.

3. Self-awareness: to know more about oneself.

4. Self-motivation: to prefer future over the past.

5. Focus on the most important task.

6. Decision-making: using time and resources quickly to complete the tasks and goals.

7. Planning: using the right way and method.

8. Communication skills: building supportive relations with people one works with.

9. Questioning and challenging: clarify and challenge anything and everything which does not meet one's standards.

10.Delegation/outsourcing: the job should be done by the right person to the highest standards at the right time.

11.Coping skills: the ability to determine the results and cope with setbacks.

12. Stress management: the ability to understand that it is wise to prevent the problem than to deal with it when it happens.

13. Record keeping: keeping records will save a lot of time in the future.

14. Organization and filing: deciding the right thing to do at the right time.

15.Patience and forgiveness: the best managers do not rush things, they have patience.

16.Forgiveness: it is not time management skill, it is life skill that helps communicate with people successfully [2].

Figure 1 contains the Priority Matrix beneficial for reviewing and grading the tasks in accordance with appropriate categories on a daily basis:
- which of the tasks should be done within 48 hours;

- which of the urgent tasks are most important;

- which of non-urgent tasks are more important [12].

Each box of the Priority Matrix should not contain more than seven or eight tasks. It is advisable for students to start with the "Do Now" box not postponing unpleasant urgent and important tasks.

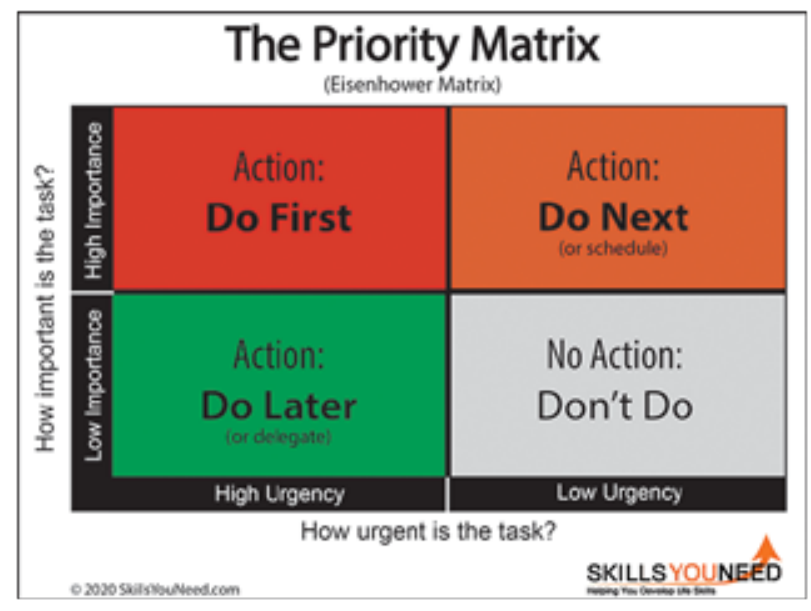

Fig. 1. The Priority Matrix [12]

Less urgent and easier things may be deligated while both non-urgent and non-important tasks must be eliminated. It is worth mentioning that the task list needs regular daily reviewing since the issue of urgency and importance is not fixed, hence its status may be changed.

In most of the professions time management is of highest priority. It is also the key to good time organization and distribution that lead to the academic success. Unfortunately, quite a big number of students learn without taking into consideration time management. Without enough time to study, they try to get the highest marks and are then disappointed when the results are unsatisfactory.

Coming out of the developed general time management skills mentioned above we can extrapolate, construct and implement such skills for EGP and especially ESP students. J. MacKay in his work "Time management for students: ten strategies and tips to maximize your time and build your focus" [8] proposes ten strategies and tips for students to master time management skills in the context of ESP discourse: the first strategy recommends using a daily schedule template to plan one's day. This adage focuses on making up a schedule of one's own time rather than a to-do list. To organize a successful schedule the student should be aware of how he/she begins and finishes each day, he/she should set apart 
time for the most important tasks and plan the time for social time, breaks etc. The second tip concerns the process of understanding how you spend one's time. The author introduces the term 'time log' where a person controls each moment of his/her spent time and 'rescue time' registering where he/she uses time unproductively for creative effective time management habits. The third strategy deals with a very critical issue of setting proper goals for achieving the ultimate goal. It covers the idea of proper dozing the time of fulfilling daily goals that will lead to the final effective result. The fourth tip goes to the issue of breaking large projects into small tangible tasks. For example, if someone is going to write a serious essay he/she can divide that project into smaller tasks: to search for the literature in question and analyze the contents, to write out an outline, to write short abstracts to each item of the plan etc. Speaking about the fifth time management habit the author teaches how to counteract the planning fallacy making up reserve time, e. g. the double time to cope with the task without being stressed. Strategy number six recommends the students to follow body's natural energy ups and downs. Every person follows his/her own rhythm, but usually the majority of people follow one and the same model.

The seventh skill concerns the habit of having breaks at a right time. According to the researcher N. Kleitman our mind usually needs breaks after ninety minutes of intensive work and our body will signal when we need a break [7]. When it comes to that one should stop working, go for a short walk if possible, give eyes a rest and take something to eat. The eighth strategy is related to the skill of reducing procrastination to about five minutes. The matter is that a person should get motivated and in order to do that one must follow the five-minute rule, that is, telling oneself to spend only five minutes of work on the project. In most cases it gets a person motivated. The ninth tip for time management skills embraces the habit of doing only one thing at a time. When the schedule is crammed it is very tempting to perform many tasks. Nevertheless it is more productive to do a single task at a time. But in order to properly cope with a single task it is necessary to take the following steps: take away all distractions, set a timer and take breaks after each period of work. The tenth and last strategy concerns the postulate of building better habits and routines for long-term success. The best time management strategy for students and everyone else is simply to develop habits and routines that promote the kind of actions you want to do more of. Time management for students is not that easy.
Figure 2 summarizes most important time management tips [11], namely: 1) setting goals correctly; 2) prioritizing wisely; 3) setting a time limit; 4) taking breaks between tasks; 5) organizing oneself; 6) removing non-essential tasks; 7) planning ahead.

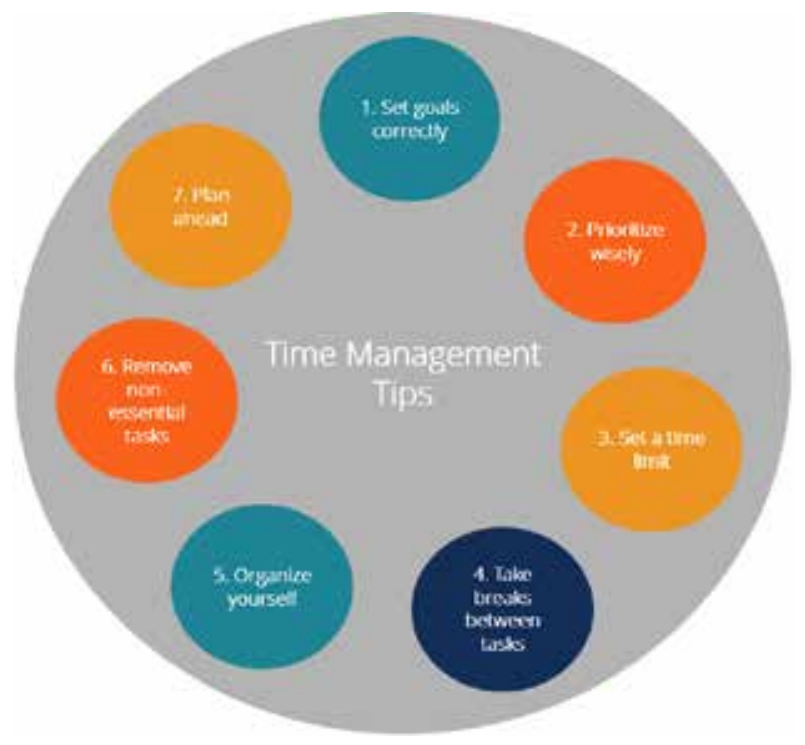

Fig. 2. Time Management Tips [11]

B. J. C. Claessens, W. van Eerde, C. G. Rutte and R. A. Roe in their article "A Review of Time Management Literature" give a thorough literature review and analysis of the problem under consideration defining time management as "behaviours that aim at achieving an effective use of time while performing certain goal-directed activities" [5, p. 262]. According to this definition time is treated not as the aim in itself. It is the effective use of time spent on some goal-directed activities or, in other words, a certain behaviour which is in the focus of attention. The authors distinguish several behaviour types:

- time assessment behaviour responsible for accepting tasks which correspond to the limits of one's capabilities;

- planning behaviour correlated with an effective use of time in terms of setting goals, prioritising, making to-do lists, planning/grouping tasks etc.

- monitoring behaviour aimed at controlling one's use of time in the course of performing activities, checking at the same time feedback in order to limit the influence of interruptions by others [5, p. 262-263].

Besides behaviour "there are numerous factors influencing the efficient organization of time: technical errors, external realities or psychological obstacles" as stated in the article "Time management: skills to learn and put into practice" by M. Alvarez Sainz, A. M. Ferrero, A. Ugidos [4, p. 6]. The arti- 
cle reads that "the knowledge society determines a work scenario in which it is essential to manage time efficiently; a non-innate skill that should be learned at the university" [4, p. 6], since it is not the amount of time being available which counts but the use of it. Findings testify to the fact that in the majority of cases students focus on short-term planning and demonstrate the lack of self-organization and prioritization skills in the long term learning. Because of that the authors regard time management as part and parcel of educational process in general and higher education in particular arguing that "if one of the objectives of the university is to prepare students for their labor insertion, time management becomes an essential competence for the link of formation with the professional world" [4, p. 4].

The research study "A Practical Application of Time Management" by D. George from Canadian University College, Canada, identifies that "clear goals and time-management skills rank as the most important factors in personal or academic success and far outrank items such as study time, emotional stability, locus of control, or IQ" [6, p. 57]. The author also points out that it is highly important to plan and regulate only the most important areas of one's life leaving other areas of life well-ordered for the rest of things just happen automatically.

J. van der Meer (Higher Education Development Centre, University of Otago, Dunedin, New Zealand), E. Jansen (University of Groningen, Groningen, The Netherlands) and M. Torenbeek (University of Groningen, Groningen, The Netherlands) in their work "It's almost a mindset that teachers need to change": first-year students' need to be inducted into time management argue that "universities could and should play a more active role in helping first-year students to make sense of time management" [10, p. 777] due to learning environment changes, modern approaches to learning and technological developments. It is stated that Virtual Learning Environment offers great opportunities to support students in developing the necessary skills for planning their time and studies in a proper way to be able to meet the requirements of the changed mode of tertiary educational process.

N. Talib (National University of Modem Languages) and S. S. Sansgiry (University of Houston) in the paper "Determinants of Academic Performance of University Students" regard time management techniques as the best ways for managing course material. Through group study method, which has been taken as the example, students can have discussions exchanging ideas on certain topics, memorizing in this way their active vocabulary and key points which help them to achieve better results [9, p. 274].

A. S. Al Khatib (College of Business Administration, Al Ain University of Science and Technology, United Arab Emirates) studying time management and its relation to students' stress, gender and academic achievement among sample of students at Al Ain University of science and technology, UAE, underlines that "good time management such as setting goals and priorities as well as monitoring the use of time can facilitate productivity and minimize stress, contributing to work effectiveness, maintaining balance and academic success" [1, p. 47].

Conclusions. Time management being a key ability and a fundamental skill properly taught and developed to increase the would-be- specialists' competitiveness in the current work market as well as their future successful functioning in the professional environment due to effective organization of the priorities and activities as a result of critical thinking, planning, defining objectives and developing strategies, team work, decision-making, problem resolving also influences a lifelong learning. Hence, all aspects of time management are highly evaluated within the EGP and ESP mastering and should be incorporated into tertiary educational process.

\section{References:}

1. Al Khatib A. S. Time management and its relation to students' stress, gender and academic achievement among sample of students at Al Ain university of science and technology, UAE. International Journal of Business and Social Research. 2014. Vol. 4. № 5. P. 47-58.

2. Allen D. Getting Things Done: The Art of Stress-free Productivity. London : Penguin Books Ltd, 2002. $267 \mathrm{p}$.

3. Allen D. The Organized Mind. London : Piatkus, 2015. 352 p.

4. Alvarez Sainz M., Ferrero A. M., Ugidos A. Time management: skills to learn and put into practice. Education and Training. 2019. URL: https://www.researchgate.net/publication/330977996_Time_management skills_to_learn_and_put_into_practice.

5. Claessens B. J. C., van Eerde W., Rutte Ch. G., Roe R. A. A Review of Time Management Literature. Personnel Review. 2007. Vol. 36. Iss. 2. P. 255-276. DOI: http://dx.doi.org/10.1108/00483480710726136.

6. George D. A Practical Application of Time Management. Time Management / ed. by T. Stoilov. URL: https://www.intechopen.com/books/time-management/a-practical-application-of-time-management. 
7. Kleitman N. Current Research on Sleep and Dreams. Washington : Public Health Service Publications, 1965. $125 \mathrm{p}$.

8. MacKay J. Time management for students: 10 strategies and tips to maximize your time and build your focus. URL: https://blog.rescuetime.com/time-management-for-students/.

9. Talib N., Sansgiry S. S. Determinants of academic performance of university students. Pakistan Journal of Psychological Research. 2012. Vol. 27. № 2. P. 265-278.

10. Van der Meer J., Jansen E., Torenbeek M. "It's almost a mindset that teachers need to change": first-year students' need to be inducted into time management. Studies in Higher Education. 2010. Vol. 35. № 7. P. 777-791.

11. Time Management Tips : image. URL: https://cdn.corporatefinanceinstitute.com/assets/time-managementtips-diagram.png.

12. The Priority Matrix : image. URL: https://www.skillsyouneed.com/images/priority-matrix.png.

\section{Байбакова І. М., Гасько О. Л. НАВИЧКИ УПРАВЛІННЯ ЧАСОМ ЯК НЕВІД'ЄМНА ЧАСТИНА ОПАНУВАННЯ ДИСКУРСУ АНГЛІЙСЬКОЇ МОВИ ПРОФЕСІЙНОГО СПРЯМУВАННЯ}

Проблема управління часом вивчалася багатьма дослідниками. Статтю присвячено найважливішим стратегіям $і$ відповідним навичкам, які необхідні студентам для їхнього успішного навчання та майбутньої професійної діяльності.

Завдяки сучасним підходам до освіти, технологічному розвитку та відповідним змінам щяодо умов і середовища навчання необхідно підтримувати студентів у набутті навичок планування часу. Управління часом розглядається як його ефективне використання, витрачене на певну иільову діяльність у термінах оцінки часу, планування й моніторингу.

Результати свідчать, що в більшості випадків студенти зосереджуються на короткостроковому плануванні, демонструючи відсутність навичок самоорганізачї в довгостроковому навчанні. Ось чому їх необхідно навчити звертати увагу на такі аспекти: 1) правильне встановлення иілей; 2) визначення пріоритетів; 3) встановлення обмеження часу; 4) важливість перерв між завданнями; 5) самоорганізацію; 6) усунення несуттєвих завдань; 7) планування наперед.

Методи управління часом розглядаються як найкращий спосіб опанування навчального матеріалу. Наприклад, завдяки застосуванню методу групового навчання студенти можуть вести дискусіі, обмінюватися ідеями щодо певних тем та запам'ятовувати активну лексику, що допомагає їм досягти краших результатів, сприяє продуктивності й мінімізує стрес.

Управління часом - че ключова здатність та основна навичка, яку необхідно опанувати для підвищення конкурентоспроможності майбутніх фахівців на сучасному ринку праці, а також для майбутнього успішного функиіонування їх у професійному середовищі завдяки правильному плануванню, визначенню конкретних иілей і пріоритетів та застосуванню корисних стратегій, що своєю чергою впливає на ефективність командної роботи, прийняття рішень, вирішення проблем і навчання впродовж усього життя. Таким чином, усі аспекти управління часом повинні бути включені до навчального процесу.

Ключові слова: управління часом, вища освіта, викладання, навчання, иілеспрямована діяльність, навички, пов'язані з роботою, дискурс англійської мови за професійним спрямуванням. 